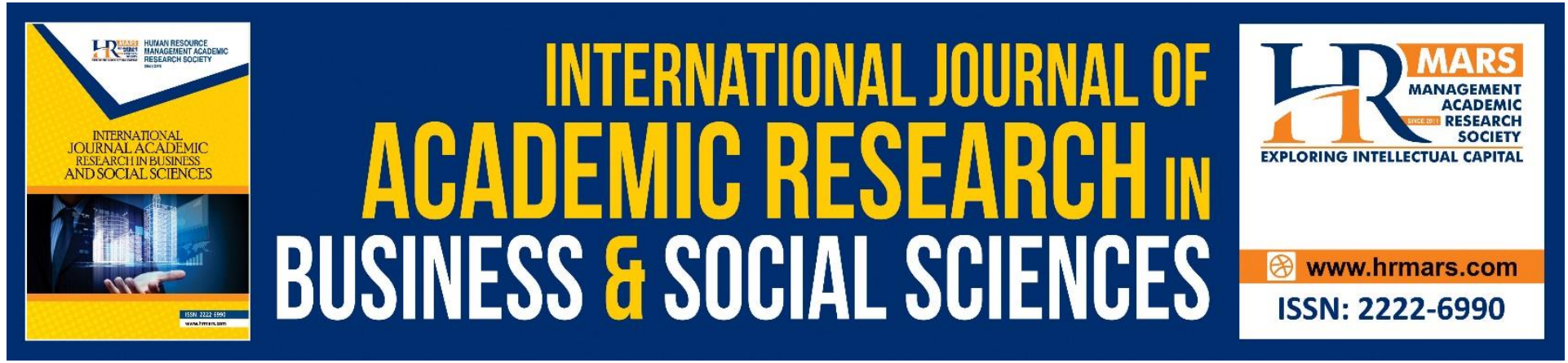

\title{
Understanding Source Credibility in The Doktor Muda Programme: A Focus Group Discussion
}

Mohd Razif Zakaria, Normah Mustaffa, Emma Mirza Wati Mohamad

To Link this Article: http://dx.doi.org/10.6007/IJARBSS/v11-i8/10678

DOI:10.6007/IJARBSS/v11-i8/10678

Received: 02 June 2021, Revised: 29 June 2021, Accepted: 17 July 2021

Published Online: 05 August 2021

In-Text Citation: (Zakaria et al., 2021)

To Cite this Article: Zakaria, M. R., Mustaffa, N., \& Mohamad, E. M. W. (2021). Understanding Source Credibility in The Doktor Muda Programme: A Focus Group Discussion. International Journal of Academic Research in Business and Social Sciences, 11(8), 91-112.

Copyright: (c) 2021 The Author(s)

Published by Human Resource Management Academic Research Society (www.hrmars.com)

This article is published under the Creative Commons Attribution (CC BY 4.0) license. Anyone may reproduce, distribute, translate and create derivative works of this article (for both commercial and non-commercial purposes), subject to full attribution to the original publication and authors. The full terms of this license may be seen at: http://creativecommons.org/licences/by/4.0/legalcode

Vol. 11, No. 8, 2021, Pg. 91 - 112

Full Terms \& Conditions of access and use can be found at http://hrmars.com/index.php/pages/detail/publication-ethics 


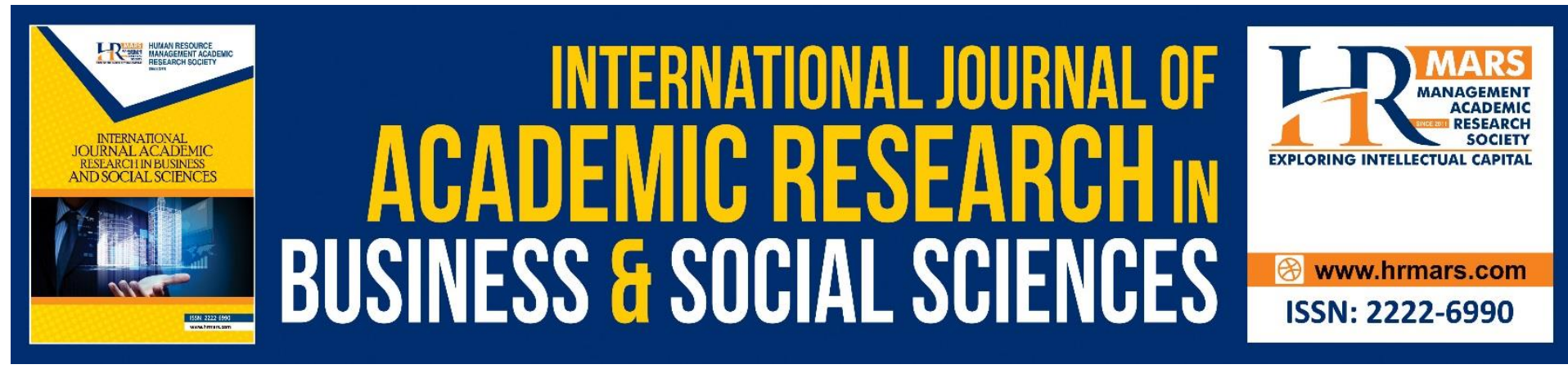

\title{
Understanding Source Credibility in The Doktor Muda Programme: A Focus Group Discussion
}

\author{
Mohd Razif Zakaria, Normah Mustaffa, Emma Mirza Wati \\ Mohamad \\ Pusat Kajian Media dan Komunikasi, Fakulti Sains Sosial dan Kemanusiaan \\ Universiti Kebangsaan Malaysia, 43000, Bangi, Selangor, Malaysia \\ Email: fizz79my@yahoo.com,normahm@ukm.edu.my, emmamohamad@ukm.edu.my
}

\begin{abstract}
Sources play a vital role in the dissemination of information. This also applies to the Doktor Muda programme in schools. The members of the Doktor Muda club are responsible for conveying health information to their peers in school. Prior to this process, these students were trained by the advisor teachers based on the guidelines in the Doktor Muda programme practise module. Thus, this study was conducted to examine students understanding of the source credibility need dimension that should be possessed by students before they were selected and appointed as a member of the Doktor Muda. This study involved 40 students from five Doktor Muda Centre of Excellence schools as informants. The data were collected through focus group discussions. Based on the finding of the focus group discussion, the informants believe that there are four source credibility dimensions that should be possessed by students before they were appointed as the member of the Doktor Muda. These dimensions are trustworthiness, competence, attractiveness, and dynamics. Each dimension is grounded on the different source capability dimension criteria. The finding of this study is hoped to help policymakers in the Ministry of Health and Ministry of Education to review the condition and process in selecting and appointing a member of the Doktor Muda in schools.
\end{abstract}

Keywords: Source Credibility, Trustworthiness, Competence, Attractiveness, Dynamics, Health Promotion.

\section{Introduction}

In the field of health communication, source credibility is thought to increase the trustworthiness of a message and subsequently can help change an individual's trust and behaviour (Pornpitakan, 2004). Therefore, source credibility plays an important role in persuasion. Source credibility is perceived to have a positive impact on the effectiveness of message delivery (Roger \& Gunther, 2017). Credibility is also seen as a source of information that plays an important part in decision-making (Pornpitakkan, 2004). This is because a credible presenter is able to have a significant impact on the receivers, affecting their attention and behaviour (Eisend, 2006).

According to Aristotle, source dimension comprises three criteria, which are intelligence, character, and good will criteria, while Hovland, Janis and Kelly (1953) explained 
that source credibility consists of the dimension of expertise, trustworthiness and intention towards the receiver. In the meantime, according to Berlo and Lemert (1961), credibility depends on the dimension of competence, trustworthiness, and dynamics. Source credibility also involves the dimension of expertise, trustworthiness, and caring (McCroskey et al., 2006).

A study based on the source credibility theory (Hovland, Janis \& Kelley, 1953) found that source and trustworthiness are the two main factors in the measurement of credibility. The main factors that influence an individual to trust a message are the credibility of the source obtained from an individual or an organization (Hovland, 1953). In this regard, source credibility is dependent on the credibility of the statement that the source is credible and can be trusted (O'Keefe, 1990).

According to Wathen and Burkell (2002), credibility is a criterion used to filter information. However, the definition of credibility has become more complex when it is linked to the presenter or the source of information. Metzger and Flanangin (2008) argued that the role of source in credibility lies in the persuasive nature of the message. In general, research on source credibility has been focused on the criteria of message sources such as the presenter, organisation, or news organisation (Golan, 2010).

\section{The Background of the Doktor Muda}

The Doktor Muda programme is a smart partnership programme between the Ministry of Health $(\mathrm{MoH})$ and the Ministry of Education (MoE). It is based on the concept of empowerment by using primary school students as an agent of change to influence the health knowledge, attitude, and behaviour of their peers. Doktor Muda consist of upper primary students who were chosen by the school and trained according to the Doktor Muda programme training module.

The effectiveness of the Doktor Muda in influencing the health knowledge, attitude, and behaviour of their peers depends on their knowledge, skills, and confidence in using communication strategies taught to them and their understanding and skill in using the input given by teacher advisors based on the guidelines in the Doktor Muda training module during the co-curriculum session in school

School is the best environment to cultivate good health practises. Health Promoting School, which was introduced by the World Health Organisation (WHO) in 1996, is seen as a strategy in Promoting health in school (WHO, 1996). At the Ministry of Education and the Ministry of Health level, a healthy school integrated programme has been established as a platform to promote healthy activities in school. This smart partnership programme between the Ministry of Health and the Ministry of Education is hoped to produce a new generation that prioritises healthy living.

The Doktor Muda programme has been introduced in schools in 1989. In 2006, the Ministry of Education Malaysia had accepted the Doktor Muda programme as one of the cocurricular activities in primary school. In 2018, a total of 3286 primary schools had conducted this programme. The Doktor Muda programme is aimed at a healthy lifestyle through the empowerment concept. This programme is meant to produce a group of students that prioritise health and act as an agent to promote a healthy lifestyle among their peers and the school community and their family members (BPK, 2018).

The Doktor Muda are students selected by the school based on several criteria. These students will be trained in terms of knowledge and skills in several relevant aspects of health based on the Doktor Muda training module. These students will act as peer educator and agents of change to improve health-based knowledge, attitude, and practise s in schools. 
This programme is grounded on the concept and strategy of health promotion, which is in line with the healthy school integrated programme. This programme is also a form of smart partnership between the MoE and the MoH with the support of other agencies. This is aligned with the aspiration of the health ministry, which is focused on the concept of collaboration in health services.

The programme is based on the concept of 'from students to students for students'. It presents the proactive approach that needs to be taken in primary schools, which have shown certain health issues to fulfil the aspiration of producing healthy, fit, and smart students (BPK, 2018).

\section{Problem Statement}

The implementation of the Doktor Muda Programme is aimed to enhance and empowering a group of school students with the basic knowledge and skills on health. Doktor Muda members will, in turn, act as peer agents or mentors in promoting good health practises among their peers and the school community. This program aims to produce students who cultivate healthy lifestyle practises. This collaborative programme between $\mathrm{MoH}$ and $\mathrm{MoE}$ begins with a training session for all Advisory Teachers using the Doktor Muda Training Module, the Doktor Muda Curriculum Guidelines, and the Co-Curriculum Guidelines for Peer Mentors. The Advisor Teacher will conduct training sessions for Doktor Muda members at the school level during the co-curriculum slot, there is a total of between 12 sessions to 22 sessions per year. All Doktor Muda members will be trained by the Advisor Teacher using the same module and the teaching aids provided by the $\mathrm{MoH}$ and $\mathrm{MoE}$ or materials produced by the school itself.

Thus, students who appointed as members of the Doktor Muda play an important role in conveying health information and implementing healthy lifestyle activities among their peers. $\mathrm{MoH}$ and $\mathrm{MoE}$, through the Co-Curriculum Guidelines, have set 14 compulsory activities that need to be implemented by Doktor Muda in promoting a healthy lifestyle to their peers. The implementation of these activities should be recorded in the Doktor Muda activity logbook. These reports will be sent to the state and federal levels for analysis. As the implementation of this activity is subject to the Co-Curriculum Act, all students aged 10 to 12 are eligible to be appointed as members of the club without any discrimination. However, their appointment is subject to the criteria outlined in the Doktor Muda Constitution. Due to the limited number of membership, there are schools that have set certain criteria to choose the members. Some schools have chosen Doktor Muda members based on the results of special tests, interviews, and academic excellence. There were also issues raised involving teachers preferences towards a particular student.

The focus group interviews conducted during the Effectiveness Study of Peer Education through Doktor Muda in 2017 found that students have little trust over the message disseminated by their peers in the Doktor Muda because the Doktor Muda themselves do not practise a healthy lifestyle. This is unfortunate as the Doktor Muda should provide an example of healthy lifestyle practises to their friends.

The same study found that the students have very low knowledge of health issues. Out of the 6 components of health measured, the findings show that the students' knowledge is low in all components, which are healthy eating (7.6\%), active lifestyle (2.1\%), ideal weight (1.9\%), hand hygiene (26.2\%), dental health $(2.7 \%)$ and not smoking (17.1\%). These findings seem to indicate that the gaps or failures in the Doktor Muda' delivery of health information 
to their peers. This result may be related to the student' very low trust towards their peers in the Doktor Muda members.

A study in Kuala Terengganu found that the Doktor Muda and their peers are not skilled in demonstrating the 7 steps of handwashing (Ali, 2015). The findings of this study show that the Doktor Muda themselves are not competent with the skills that they must practise daily. This finding indirectly shows the weakness of the Doktor Muda as a source of health information and peer educator.

Jaafar (2010) in his study found that Doktor Muda fail to convey information properly to their peers. The study reported that students think that only $40 \%$ of Doktor Muda members have the confidence to conduct public speaking to share health information with their peers. The low self-confidence among Doktor Muda members indirectly gives a negative perception of the club among their peers. As the Doktor Muda Club Constitution clearly states that the Doktor Muda members should be selected from among students who are interested, leadership characteristics, and influential. Doktor Muda club members selected and trained by the school should have high self-confidence, especially when conveying health information in front of their peers. Therefore, schools should be aware of students' abilities before appointing them as a Doktor Muda.

Another study conducted by Ibrahim, Sutan \& Abd Manaf (2019) found that Doktor Muda members do not play the role as peer educators, which is one of the goals of this program. This failure is attributed to the lack of interaction between the Doktor Muda and their peers while conveying information. Some Doktor Muda members only read the text provided by the teacher. These findings indicate that students prefer the information to be presented in more interesting ways and through a variety of methods by their peers. Therefore, Doktor Muda members should convey health information to their peers in a more interactive way.

Based on the findings discussed above, there is evidence that some members of the Doktor Muda club fail to act as peer educators. As a result, it was found that students do not trust the Doktor Muda, do not consider Doktor Muda as role models. In this regard, students think that Doktor Muda have low confidence, their delivery is not attractive, and they are incompetent. These perceptions are directly related to the credibility of students appointed as Doktor Muda. While the role and responsibilities of this Doktor Muda have been described in Scope 1 of the Doktor Muda and Teacher Advisor Training Module, the advisor teachers should explain the role and responsibilities of the Doktor Muda during the first week of the club meeting.

The studies found that their peers have raised the credibility issue in the selection of students for the Doktor Muda. A researcher, feels that a study on the credibility of student selection should be implemented so to help the Ministry of Health to form a guideline on the resource credibility dimension in implementing health promotion programmes. This could be done through empowering and enabling the members of the community as health information agents. Aside from investing millions of ringgits, there is a need to ensure the sustainability of the health promotion program in schools so that it has a good impact in shaping healthy behaviour among school children in Malaysia.

\section{Research Objectives}

This study aims to see whether the peers of the Doktor Muda members understand and demonstrate the resource credibility dimensions in the Doktor Muda program. 


\section{Research Methodology}

This study used the focus group discussion method (FGD) in 5 schools, which are selected as the Centre of Excellence for the Doktor Muda. This study involved eight students age 12-yearold students from each school who were selected by the advisor teacher. Selected students have never been appointed as members of the Doktor Muda and have attended the school since year 1. A total of 40 students were involved in the focus group discussion. The schools involved are SK Kampung Berangan, Pasir Putih Kelantan, SK Seri Biram, Pekan Pahang, SK Sri Iskandar, Perak, SK Bandar Teknologi Kajang, Selangor, and SK Mukah, Sarawak.

The implementation of the focus group discussions helps researchers to obtain information about the students understanding of the criteria and dimensions of source credibility that should be possessed by members of the Doktor Muda. This is because Doktor Muda play an important role in conveying health information to their peers. Each informant was given a unique identification as shown below, due to the research ethics.

Table 1.1 The number of informants and informant identity

\begin{tabular}{lcccc}
\hline School & State Code & $\begin{array}{c}\text { Number of Male } \\
\text { informants }\end{array}$ & $\begin{array}{c}\text { Number of } \\
\text { female } \\
\text { informants }\end{array}$ & Total \\
\hline $\begin{array}{l}\text { SK Kg. Berangan, } \\
\text { Kelantan }\end{array}$ & $\mathrm{D}$ & 4 (DL1- DL4) & 4 (DP1-DP4) & 8 \\
SK Mukah, Sarawak & $\mathrm{Q}$ & 4 (QL1- QL4) & 4 (QP1-QP4) & 8 \\
$\begin{array}{l}\text { SK Sri Iskandar Perak } \\
\text { SBT SK Seri Biram, }\end{array}$ & $\mathrm{A}$ & 4 (AL1- AL4) & 4 (AP1-AP4) & 8 \\
$\begin{array}{l}\text { Pahang } \\
\text { SK Bandar Teknologi }\end{array}$ & $\mathrm{C}$ & $4(\mathrm{CL1}-\mathrm{CL4})$ & 4 (CP1-CP4) & 8 \\
Kajang, Selangor & $\mathrm{B}$ & 4 (BL1- BL4) & 4 (BP1-BP4) & 8 \\
\hline
\end{tabular}

\section{Results}

The informants in all focus groups were asked to answer each question posed on their understanding of the criteria and dimensions of resource credibility that must be present in members of the Doktor Muda. The data obtained were analysed using NVIVO software version 10. The findings were classified into several themes to answer the objectives of the study based on source credibility criteria. The researcher formed questions based on the study's objectives and collected the answer according to the themes, or specifically, the dimensions of source credibility. The findings of the focus group discussion will be discussed in detail according to the theme of the source credibility dimension, based on the informants answers. The researchers divided the results of the focus group discussion into four main themes, which consist of four source credibility dimensions, trustworthiness, attractiveness, competence, and dynamics.

\section{Dimensions of Trustworthiness}

Based on the data from the focus group discussion, the researchers found that the informants from each school provided input that can be categorised under the theme of trustworthiness dimension. The findings under this theme are described according to the sub-themes as share by the informants. These subthemes are the criteria of attractive character, knowledgeable, and admirable personality. The information shared by the informants is in line with previous studies, which emphasised the criteria of attractive characters and admirable personality. In 
this light, the findings of the focus group discussion conducted provided a new criterion, which is knowledgeable. This criterion was not discussed as one of the criteria in the dimensions of trustworthiness in Hovland and Weiss, Berlo and Lemert, Bower and Philips, Whitehead, McCroskey, Ohanian, and White as the criterion to build the students' trust towards the Doktor Muda as the source of health information.

\section{Attractive Character}

The informants believe that this criterion is important for a Doktor Muda to gain the trust of peers. According to the informant, a person with an attractive character is a person who has a good appearance and good communication skills. They could be an example or role model to peers and become an inspiration to other peers.

QL4: “...because... Alvin (Doktor Muda) he was once fat...he practise healthy eating ... then he becomes thin."

QL3: "they always practise the things they advise us to do."

The informants' statements above highlight the seriousness of a Doktor Muda member, Alvin, to make changes to his weight. As a result, he becomes an inspiration and role model to his peers. The statements of these informants from Sarawak are also supported by other informants who stated that the appearance of the Doktor Muda is very important.

QP4: " ha... their appearance, they are clean, they have a good appearance."

M: "Doktor Muda should have a good appearance.

CL2: " they are a good example for us, their cleanliness, their clothes."

BL2: "their personality, they are very clean."

DL4: "because the Doktor Muda have white, shiny teeth."

The informant also stated that to become a Doktor Muda member, a student must possess good communication skills. The informants felt that communication skills are essential. According to them, Doktor Muda who do not have good communication skills may not have the courage to speak in front of their peers to conveying information. In addition, the Doktor Muda should also have a loud and clear voice so that the message they want to convey can be heard and understood clearly by others.

DL4: "talk aloud."

CP3: "dare to talk in front of people."

CL2: " they need to have a clear and loud voice."

M: " a loud and clear voice, ok, why?"

CL2: " so other students can hear what they are saying."

\section{Knowledgeable}

The informant opined that Doktor Muda members should be knowledgeable. The informants also added that Doktor Muda' knowledge reflects the virtues of intelligence, skillfulness, informativeness, competence, and wisdom. According to the informant, a knowledgeable Doktor Muda is able to gain the trust of his peers.

All informants from Perak and Sarawak suggested that as a peer educator, Doktor Muda should be selected from students who are knowledgeable. They also believe that the knowledge possessed by the Doktor Muda will make it easier for them to believe the accuracy of the information presented.

ALL: "intelligence ...knowledge". 
QP3: "because what they say...what they say is true".

BP2: "like some of them., after they found the information.. they will write down to tell us, sometimes the information is the same as pasted at school so there is no way they will give the wrong information to all..."

CL2: "usually the Doktor Muda give ..eerr.. the correct information... it means.."

CL4: "the information they give is the same as I found in google.. they are the same"

CP2: "aaa when they give correct information... aa.. its good for us..."

Informants feel that the knowledgeable Doktor Muda should also be skilled, and informants believe that the training provided by the Advisor Teacher during the co-curriculum slot can improve the skills of Doktor Muda. The informants believe that the Doktor Muda should be trained and possess skills in health sciences.

DL1: "skills."

ALL: "agree."

The informant also talked about the role of the advisor teachers in providing training to Doktor Muda to ensure that the selected Doktor Muda are well- trained and can play their given roles.

QP1: "they are experienced, they go around and joined many activities ..."

AL2: "because they have been trained by the teacher..."

BL1: "then teachers always teach them..."

For the informants, Doktor Muda who are knowledgeable and informative should be careful and filter the available information before conveying them to their peers to avoid confusion.

BP1: "they google the information before telling other people... like they check on the internet whether it is true or not... ask people around them."

The informant also mentioned that to become Doktor Muda that fulfil the knowledgeable criteria, the appointed Doktor Muda should come from those who are intelligent. For example, the informants from Sarawak and Kelantan agreed that students appointed as Doktor Muda must be smart.

M: "How do you think Doktor Muda members should be chosen?".

DL2: "they must be smart."

M: "from the knowledge they have, how do you think the Doktor Muda are ?".

All (Q): "they are smart."

\section{Admirable Personality}

Regarding this matter, the informants have shared some views on what they think the characteristics that should be possessed by students appointed as Doktor Muda. The informants opined that Doktor Muda need to present themselves as role models to others and possess traits such as being trustworthy, disciplined, honest, caring, punctual, and helpful to others. The informants feel that they will have higher trust towards Doktor Muda who possess admirable personality compared to Doktor Muda who do not possess these traits.

Informants from several schools stated that their trust towards a Doktor Muda member depends on the Doktor Muda' accountability in fulling their responsibilities as a Doktor Muda. They also mentioned that the appointed Doktor Muda members are entrusted by the teachers to convey information to all students. 
BL4: "because like Afif said earlier, he does his work superbly. he doesn't want to disappoint the teacher".

AL3: "because they are given the responsibility to give information to all students."

The informant also stated that Doktor Muda should be caring and helpful, especially when their friends get sick, and they are also concerned about the school environment.

QP4: "they are caring, sick students."

QP2: "school environment."

QP4: "they tell us what we do wrong..."

BP3: "he is concerned about cleanliness, personal hygience."

BP1: "because he takes care of people around him."

AL2: "caring and responsible."

BL1: "responsible, because they look disciplined, responsible, and trustworthy."

DP3: "responsible"

Being disciplined is also one of the criteria that can gain students trust toward the appointed Doktor Muda. In this light, the informant states that highly disciplined Doktor Muda will be a good example to their peers.

BL4: "discipline, he must reflect on himself before he speaks to other people because people see him as disciplined, responsible.... looks trustworthy..."

DP1: "disciplined."

AP4: "disciplined."

The informant also elaborated that Doktor Muda have discipline, specifically being punctual. According to the informant, it is important for a Doktor Muda to be on time because Doktor Muda are responsible for providing treatment assistance and carry out activities for their peers. Both activities require Doktor Muda to be on time.

BL2: "punctual."

BL1: "so like Ryan said, just now punctual..so for example, someone fell down or... ...and then..ehh they are late...or when the teachers want to conduct a meeting, then the teacher set time, so they need to arrive right on time ..."

BL2: "if someone fell down, they need to come fast... to help... maybe they will bring the first aid kit and then treat the person who hurt.. with antiseptics."

The informant shared that Doktor Muda with high discipline will be to act and respond swiftly to any instructions.

BP1: "For me, they will act fast if the teacher asks them to do something.".

Another criterion stated by the informant in the admirable personality criteria under the dimension of trustworthiness among the Doktor Muda is honesty. According to the informant, an honest Doktor Muda will be able to provide trust. Honesty refers to Doktor Muda' willingness to share health information with their peers.

CP3: "Because of their honesty, if they are honest when we ask questions, for example, we do not know about these things... if they were telling the truth, we would increase our knowledge." 
The conversation below proves that the informants, who are the peers of the Doktor Muda, do not like the Doktor Muda to lie to them by sharing incorrect information.

QL3: "Honest because we can trust them...they do not lie to us."

M: "what do you mean by lying? What do they lie about?"

QL3: "health."

The informant also shared that Doktor Muda should be helpful so that they can gain the trust of their peers.

CP1: "For me, they help me a lot.. when I try, it is true... it is true.. I can be healthy."

Based on the overall result of the FGD implemented, they are three main criteria stated by the informants on the dimension of trustworthiness in measuring source credibility. These criteria are attractive characteristics, admirable personality, and have ample knowledge. However, the informant did not mention reliability as a criterion, as reported in earlier findings. The researcher combined the criteria of attractiveness, attractive characters, and appearance as a criterion under the dimension of attractive appearance. Furthermore, knowledgeable was found as a new criterion under the dimension of trustworthiness.

\section{Dimensions of Competence}

For the theme of competence, the results of the focus group discussion indicate that there are some similarities with the criteria under the other dimensions of credibility. However, as a researcher, all the data collected were taken into account as this is the view of the informant on the required criteria to become Doktor Muda. As shown in previous studies, the criteria under the competence dimensions are intelligence, being well-trained, expertise, informative, efficiency, and intelligence. As a result of the findings of this study, there are four criteria presented by the informants, namely, efficiency, training, skills, and confidence.

\section{Efficient}

The informants stated that a Doktor Muda should be efficient. In order to possess this trait, they must be smart, focused, hardworking, goal-oriented, has strategies or plans, and able to convey accurate information to their peers.

AL4: "When people ask, he can answer, so he is considered as efficient."

CL1: " For example, when the students don't know about.. for example.. human body.. they go to the Doktor Muda.. they have to know the meaning and answer.. but not using incorrect information

Thus, the appointed Doktor Muda should not only smart, but they need to focus on what they are learning and what they are practising. This opinion was voiced by the informants in Sarawak and Perak

M: "ok, why do you say they are efficient?

ALL: Focus

M: "why need to focus?"

QL1: “ Because if they are not focused on something.. then he can make a mistake, can't become excellent.. a lot of mistakes".

The informant in Perak also agreed that an efficient Doktor Muda is someone who is focused. M: "What should they do if they want to be efficient?

AL2: "Focus.. if he is not focused, he will not achieve what he wants to convey"...

AL4: " he is not reachable...he will not get what he wants." 
M: "ok, so he needs to really focus so that he can convey what he wants ?"

ALL: "agree."

The informants also stated that to be efficient, Doktor Muda must also set goals and strategies in doing early planning to organise activities that should be implemented.

AL2: "He already knows who... he already knows his target .. goal."

M: "he has what?".

AL1: "he has a target.. what to do".:

The informants believe that the appointed Doktor Muda should be hardworking to be deemed as an efficient person.

AP4: "Work hard to get information."

AL2: "practise really hard ..."

AL4: "If we practise hard, a lot.. for example practise .., he practises to gain more knowledge.. he will become more efficient".

\section{Training}

The second criterion shared by the informant under the competence dimension is being well trained. The informants feel that training is among the most important aspect for Doktor Muda so that they can fulfil their role. The informants shared that the Doktor Muda in their school are good due to the training they received from their advisor teacher during the cocurriculum slot.

QL4: "They have been training."

M: "Is training important to the Doktor Muda?"

ALL: "important."

CP1: "If they do not train, how can they make a good presentation?"

CP2: "If there is no training, the students who are not Doktor Muda can get misunderstanding..."

DL2: "Because it's all been taught by the teacher."

Therefore, according to the informant, Doktor Muda should practise the knowledge the teachers taught them.

AL3: "They have to practise a lot of time."

M: "practise ...to make it perfect?".

ALL: "practise."

AL2: "They can find information... nowadays in technology era.. they can find information on Google or YouTube ..."

To ensure that the Doktor Muda are competent, the informant suggested that Doktor Muda always practise what the teachers taught them. One of the informants feels it is important for a Doktor Muda to practice the knowledge they regularly have before conveying it to their peers.

AL3: "They need to practise a lot."

\section{Skilfulness}

The informants also voiced that as Doktor Muda should be skillful, especially when they are showing examples or doing demonstrations to their peers. According to the informants, being 
skillful will show that a Doktor Muda has been trained, knowledgeable, aware, and ready to carry out his responsibilities as a Doktor Muda. This, in turn, will create confidence among his peers to practice what he demonstrated. However, the informant stated that to be skillful. There is a need for the Doktor Muda to combine information and knowledge is important so they can apply and practise their skills.

BP3: "He washes his hands, so he show the proper to wash hands."

BP4: "Always give an explanation about health info, and he can finish his task very fast."

When the researcher asked about the criteria that can make Doktor Muda be seen as competent, some of the informants provided answers related to knowledge and information. All informants from Sarawak agreed that Doktor Muda need to have a good knowledge in health. Similarly, the informants from Pahang stated that skilled Doktor Muda should be informative.

ALL (Q): "knowledgeable ..."

CL1: "....For example, in terms of personal hygience, when the student asks the Doktor Muda, how do they explain ... they have to answer accurately how to do ... what people can do to be healthy".

\section{Confidence}

According to the informant, the fourth criterion in the competence dimension is confidence. They agreed that Doktor Muda should have high self-confidence. This confidence can be gained if Doktor Muda have self-values such as bravery, discipline, confidence, being alert, awareness, and not easily discouraged.

AP3: "They need to be brave to talk in front of people ...like during the morning assembly, they need to be brave to come in front, they are not afraid".

BL2: "disciplined, good behaviour, he is on time, if the teacher says something, he does not talk back."

CL1: "They should not give up easily ..."

CP4: "They must always be ready."

CP4: "always ready... ready for current health issues... if there is a new disease or new information..."

CP1: "for me, to be efficient, they need to know the current situation in the school... aware".

CL2: "must act quickly."

CP1: "they also need to be aware of the condition of the canteen."

CP2: "They need high confidence."

QL1: "Confidence, they can do it without feeling nervous

Based on the findings on the competence dimension, the informants have mentioned several criteria, including efficiency, being well-trained, skillful, and confidence. These four criteria are similar to the previous findings, except for the expertise criteria, which are seen as quite impossible in the case of the Doktor Muda club as the members have not reached the level of expertise. The findings found that no informant mentioned that Doktor Muda should have expertise in their field. It is justifiable as the Doktor Muda members are the only year 4 to 6 students who were trained by the teachers as peer educators. 


\section{Attractiveness Dimension}

Attractiveness is the third theme under the source credibility dimension that researchers could obtain from the informants feedback. Based on previous studies, there are three main criteria in the dimension of attractiveness, which are likeability, familiarity, and similarity. In the meantime, based on the focus group discussions conducted with 40 informants, there were five criteria that could be established from the informants inputs, which are academic achievement, creativity, leadership, caring, and attractive appearance. The informants mentioned that the appointed Doktor Muda could possess these attractiveness criteria.

\section{Academic Achievement}

Undoubtedly this issue is one of the constantly debated issues in the implementation of Doktor Muda at the national level. It could be argued that academic excellence should not be the criterion for selecting Doktor Muda members. Hence, this criterion was not set as the condition for membership, and it is not mentioned in the club Constitution. However, as the informants are not members of the Doktor Muda club, they believe that good academic achievement is one of the benchmarks for a student to be appointed as a Doktor Muda.

BL1: "level of achievement."

M: "What do you mean?"

BL1: "Husna and Syazwan have good achievement. "

M: "What achievement?"

BL1: "Academic, co-curriculum, all..".

BL3: "he is a smart person, ... academically".

\section{Creativity}

The informant also mentioned that the Doktor Muda appointed must possess creativity. In this light, creativity comprises the way they convey information, have good voice intonation, appealing appearance, and have a sense of humour and talent.

The informants added that the use of creative teaching aids could attract their peers attention and for them to listen to information conveyed by the Doktor Muda.

CL3: "use... something as a model so that students can understand easily ".

$\mathrm{M}$ : "It is necessary to have teaching aids?"

ALL: "it is necessary."

CP2: "to make students understand what they are conveying."

The opinion of the informants from the state of Pahang was also supported by the informants from Selangor and Perak

BL2: "how they decorate the materials. "

BL1: "to attract the attention of the public."

M: "BL1, they talk to attract the attention of the public... but how about quality?"

BL1: "Good".

BL1: "like when they have a portable sink... they can use the sink as a deco to make it look interesting."

AL2: "like when they do the topic of dengue, right... they use mosquito mascot... like that. They make a cigarette model... they make big cigarettes, and they can show others what's inside .." 
The informants also shared that it is important to have an attractive appearance, good voice intonation, and use attractive ways to convey information to their peers.

CP2: "appearance... way of delivery, sometimes, they need to use a high voice tone, sometimes they need to be firm. sometimes need to be casual, but they need to convey the information clearly".

CL2: "he must have a strong and loud voice so that students can hear what he is saying."

AL3: "convey the information clearly ..".

AL1: "soft voice intonation."

Body language is also one of the characteristics that must be possessed by Doktor Muda.

AL2: "he must have style".

CL1: "they move .. make actions.. to appear stylish."

CP1: "... I think if I become a speaker, I will speak like it is a performance .."

BL1: "way of delivery."

BL1: "..they convey using song rhythm .."

The informants agreed that the element of humour or comedy is also associated with the characteristics that should be present in Doktor Muda. According to them, the element of humour or comedy is an added value to attract peers so that they do not get bored.

QP4: "funny, so that it is more interesting to hear".

$M$ : "why should there be a joke".

ALL (Q): "not sleepy."

The view on the importance of humorous elements was also voiced by informants in Pahang, Selangor, and Perak.

CL1: "need ...aa.. jokes... aa... need to have jokes and comedy".

M: "So, there must be elements of humour?"

CL1: "yes".

BL1: "funny."

M: "Is it necessary to be funny?"

ALL: "necessary."

M: "It's important to be funny."

ALL: "not important... but it is an attraction".

AP4: "like he makes jokes... mixed it a little".

$M$ : "Is there an element of humour?"

AP4: "yes".

The Informants also think to become a creative person, and one should also be versatile or talented in all aspects

BL2: "he has to be smart in all sorts of ways".

\section{Leadership}

Appointed Doktor Muda will act as peer educator in conveying health information. They play a role in promoting healthy lifestyle practises among their peers, the school community, and their family members. In line with that role, the informant also stated that leadership is one of the criteria under the attractiveness dimension. The informant stated that as a person who wants to lead, Doktor Muda need to have values as a leader. Such as having leadership talents, inspiring, confident, firms, have exemplary character, independent, helpful, proactive, and 
show maturity. The informants feel that with such self-values, a Doktor Muda leadership talent can attract other people to listen to them.

CP4: "he has to be a friendly and firm person; he should reprimand his peers if he finds any mistakes".

BP1: "firm in giving instructions, because if he wants to give instructions, he has to be firm"

DP4: "firm".

The informant also stated that Doktor Muda should become a role model and be helpful to their peers.

CL4: "For example, if we are in the canteen, even though the teacher does not tell us to do it, but Doktor Muda wants us to do it, he is a good example.

QP1: "they always help when someone is injured, give first aid".

QP2: "he advises people to be careful .."

QP3: "He always advice others not to do mistakes again .."

Informants also suggested that the selected Doktor Muda should be independent and proactive in conducting activities.

CP2: "... independent... can be independent."

CL3: "he is good at managing things, for example, activities for other students".

CL1: "Ohh.. he must have his own initiatives."

The informants also mentioned that the value of confidence should be present among the Doktor Muda. The informants explained that confidence would further strengthen the Doktor Muda' leadership criteria. This seems to give their peers the confidence to follow the Doktor Muda as their leader.

QP2: "he is not nervous... confident".

CL3: "confidence is an attraction".

CP4: "be confident if you want to be the leader; if you are not confident, people will not believe you".

BL3: "they seem to be confident because they are people who always put themselves forward during activities .."

AP3: "Be brave and feel confident to be a leader".

Lastly, the informants felt that to be a leader of his peers; Doktor Muda need to demonstrate maturity. The informant feels that Doktor Muda that demonstrate maturity, are could become a good role model to others, especially in self-management.

CP2: "that way... he shows that he is matured".

M: "mature, ok, why does he have to be mature?"

CP2: "so that other students, can trust and can follow him as a Doktor Muda".

CL4: " when he is immature, he has the same behaviour as other people who are not Doktor Muda. As a Doktor Muda, he must be able to take care of himself."

\section{Caring}

According to the informants, Doktor Muda who act as leaders should show a caring or responsible nature by showing concern and pay attention to something. 
CL4: "must be good at giving attention, giving attention to students, especially those who have problems".

DL4: "they need to take good care of other people's feelings, do not make their friends feel bad".

KP3: "he likes listening to his friends' problems".

QP3: "he is caring."

\section{Attractive Appearance}

As a leader, informants feel Doktor Muda should also look attractive by emphasizing the value of maintaining personal hygiene, brave, friendly, and cheerful. Such values are important in attracting the attention of their peers.

BL2: "brave, feel brave to go up the stage".

DP2: "brave."

DL4: "to attract attention".

AP3: "they have brave to be brave... confidence."

QP3: "Cheerful"

CP1: "I think facial expressions also play a role .. be cheerful."

In addition to being brave and cheerful, the informant also stated that Doktor Muda need to show virtues such as maintaining personal hygiene and being friendly to other people.

QP2: "appearance... because they go around... physical appearance, need to be neat, clean, they take care of their health, especially body size...personal hygience."

QL3: " he has his own style."

CP2: "he needs to dress attractively to attract students to believe in what he said".

CP3: "the way he walks, there are some people who are hunched when walking; this shows that he does not have high confidence".

DL1: "he is a clean person."

AL1: " their clothes should be neat and clean."

Doktor Muda members also need to be friendly. The informant stated that the friendliness of Doktor Muda members would allow peers to feel more comfortable socialising with them.

CP3: "he is friendly... friendly, easy to get along with other people."

CL1: "a friendly person..."

BP1: "friendly."

AP2: "not arrogant, friendly."

The findings of the attractive dimension criteria are indeed different from the results of previous studies. However, researchers feel that these findings are new knowledge that needs to be discussed and given attention to as these five criteria were raised by 12-year-old school children from 5 Doktor Muda Club Excellence Centres Schools who believe that these criteria represent the dimension of attractiveness in their mind.

\section{Dimension of Dynamics}

Dynamics is the last dimension of credibility discussed during the focus group discussions held. Among the dynamic criteria highlight in previous studies are aggressiveness, bravery, energetic, agility, and friendliness. The results of the focus group discussion show that the criteria mentioned by the informants did not stray far from the dynamic criteria dimension in the past studies. These criteria include being energetic, brave, friendliness, and aggressive. 
Furthermore, the focus group discussion found two new criteria, which are dedication and wisdom.

\section{Aggressiveness}

Doktor Muda who are dynamic should demonstrate aggressiveness such as agility and be highly spirited in conducting an activity. These traits give the impression to other students that the appointed Doktor Muda are agile in conveying the information to ensure the task given can be completed swiftly and conducted enthusiastically.

CP1: "to make it easy to complete difficult tasks, he must be fast and enthusiastic."

M: "Why did he have to be agile?"

CP2: so that work can be done easily and quickly".

\section{Bravery}

These criteria are the same as the findings of previous studies. According to the informant, bravery must be present in the students appointed as Doktor Muda. To make a Doktor Muda a brave and dynamic informant, Doktor Muda should demonstrate qualities as being firm, positive thinking, and confident, and dare to reprimand their peers.

ALL (Q): "brave."

CP2: "brave."

CL1: "Doktor Muda should be brave so that they can become examples to other students.. $"$.

CL3: "to make it easy to do difficult tasks."

AL1: "brave."

AL2: "they must be brave and firm".

AP1: "so they can convey the information clearly."

AP4: "is they are not brave... people will not believe them, they will say how come you be Doktor Muda if you are shy to speak."

The informant also believes that positive thinking is a criterion that should be possessed by the Doktor Muda so that they can feel brave.

QP3: "positive."

QP2: "if they are not positive, how can they be brave??"

DL1: "he needs to feel positive all them. He needs to say he can do it."

In the meantime, the informant also stated that his firm nature would also help Doktor Muda to be more courageous in performing their duties, especially when reminding his peers to practise a healthy lifestyle.

QL1: "firm."

QP3: "If Doktor Muda are firm, people will listen."

QP2: "He does not seem to be too gentle with people who make mistakes ... so that people who make mistakes do not do it again."

The inputs from informants in Sarawak were also supported by informants from the states of Selangor, Kelantan, Perak, and Pahang.

BL1: "firm but friendly."

DL2: "he has to be firm with his friends who are not Doktor Muda."

AL2: "Be firm, but not fierce". 
Other values that strengthen the bravery criteria mentioned by the informant is being confident. The Doktor Muda are advised to always be confident in every task and activity they perform. The failure of Doktor Muda to show confidence is feared to cause a lack of confidence among their peers.

BL2: "he has to be confident in what he wants to say... like a brave person."

BL4: "His face must be confident... cannot look nervous."

AL2: "important, if not, how do we want to believe what he said".

QP4: "If he is afraid... ahhh .. well he doesn't have what it takes to be a Doktor Muda."

\section{Energetic}

Being energetic is also one of the criteria from previous findings that were also obtained in this study. According to the informant, energetic Doktor Muda prove that they are healthy, perform their duties well, and can be an example to their peers.

\section{QP3: "energetic"}

QP2: " if a Doktor Muda is not energetic, the person who follows him will feel weird, they will be influenced and then be like him..."

CP4: "energetic"

CP3: "so that he can carry out his duties"

CL2: "so that he is aware of the surrounding situation"

CL1: "he can do heavy work"

CL4: "he can dare himself."

CL3: "can display enthusiasm to other students".

CL4: " when the Doktor Muda wants to deliver information, he must have the energy to deliver it... should not look weak".

KL2: " in order to be energetic... they must be healthy".

The results of the study also show quick thinking or agility, health, cautions, and calmness are important values in the energetic criteria. Overall, according to the informant, agility shows that Doktor Muda is an active person, can be an example to his peers and able to provide help when needed.

QL1: "quick thinking."

QP4: "If someone is sick, they can help quickly, "

CL3: "because... if the Doktor Muda is not healthy, how can he help his friends..."

CP3: "he has to be cautious and calm, for example... if there is an accident and he needs to do first aid... if he is not calm and feels anxious... how can he help the sick person? ..". AL2: "he must be healthy... it is a must."

AL3: "Agree... quick thinking"

\section{Friendliness}

Friendliness is another criterion stated by the informants. The informants believe that this criterion is necessary for those who want to become Doktor Muda. In this regard, Doktor Muda should have good communication skills, not shy, cheerful, and easy-going. Having a friendly personality is important as it allows the Doktor Muda to exchange ideas with their peers, as well as create a friendly relationship between them. The informant added that friendly character would make the Doktor Muda more approachable and it could help to communicate better with their peers. Doktor Muda are also advised to always be cheerful in order to be an example to their peers.

CP4: "friendly" 
CP3: "so that he can easily communicate."

CL3: "so that we can exchange ideas."

CP2: "so that people can easily approach him."

BL1: "friendly."

AP3: "he has to be friendly to talk."

AP2: "yes ... be friendly".

The informant agreed with the moderator's view that to become a friendly person; Doktor Muda should not be afraid to speak to others. All informants from all schools agreed that communication is important to become more friendly and generate a lot of ideas and information.

CP3: "can give ideas, convey information when they can talk".

CL3: "I'm the type to talk a lot... they also need to talk a lot."

AL2: "it is necessary for them. if not, what kind of information they want to share with us."

DL3: "it is difficult if they are shy... if they do not talk... other students will not get the information."

To become more friendly, Doktor Muda also need to have cheerful, easy-going, and not shy. The informants opined that Doktor Muda should have these traits so that they can become role models to their peers

CL3: "always show a cheerful face.., Even though they have a lot of work."

CP3: "they should not show unhappy face in front of other students during activities... they must smile, not shy... friendly".

CL3: "aah because if you are not happy, the Doktor Muda will not get the attention of the students.

CL2: "they need to be cheerful, friendly, and don't be shy so that students can follow it..."

\section{Dedication}

Dedication is another criterion focus during the focus group discussions. According to an informant, a dynamic Doktor Muda needs to be dedicated or committed to carrying out his duties. Thus, the informants described those who are dedicated as committed, caring, capable, diligent, sincere, meticulous, and cooperative.

QP3: "I want a dedicated Doktor Muda."

CP3: "Dedicated... he has a function...because if he has no desire to do something, he will have no spirit or aura to do so."

A dedicated Doktor Muda should be diligent, cooperative, versatile, sincere, committed to the task, meticulous, and caring, especially in helping his peers and during group work. This is because Doktor Muda are required to perform their tasks in small groups.

QL4: "be diligent. So that they look strong and committed to doing the work."

CL1: "he performs a task with other members... he has to be diligent too."

DL1: "be diligent....ermm.. he is doing it wholeheartedly."

BP3: "...he has to be diligent... and show that he cares about what he needs to do with other Doktor Muda."

BP2: "because they always do in a group... there is a small group to meet friends." 
AL3: "Some of them always ask their friends if they having problems, show them how to do things, they will teach their friends if they do not know how to do things. They show that they care."

CP2: "they are always cooperative."

BL2: "They seem to be multitaskers... they can do everything."

CP4: "the important thing is that this person works sincerely".

\section{Wisdom}

Wisdom or being wise is a new criterion obtained from the informants of the focus group discussion. The informants believe it is necessary for Doktor Muda to be wise, dynamic, able to make decisions, active, and far-sighted.

BL1: "far-sighted.... when you do something.. you must want to see results".

QP4: "The smart one has a lot of knowledge..."

CL4: "He has to be wise; if he is not wise, he will not get any resources ..."

CP4: "can make a decision and do the right thing."

BL2: "he is intelligent and has an active brain is fit".

The informants also feel that a wise person should also be active. This is because they believe that an active person will have a healthy brain.

QP4: "he has to be active so that his brain is healthy."

CL3: "he has to be active too."

DL4: "Doktor Muda are wise; most of them are active."

\section{Discussion}

During the focus group discussions, the informants stated four (4) dimensions of source credibility in the selection of Doktor Muda club members. These dimensions are trustworthiness, competence, attractiveness, and dynamics.

In regard to the trustworthiness dimension, the informants stated three main criteria, namely attractive character, admirable personality, and knowledgeable. These findings support the trustworthiness dimensions highlighted in Hovland \& Weiss (1951); Berlo \& Lemert (1961); Bower \& Philips (1967); Whitehead (1968); Mc Croskey (1999); Ohanian (1990) and White (1990).

The results also show competence as the second dimension of source credibility. According to the informants, the competence of Doktor Muda club members can be measured based on several criteria., such as efficiency, being well-trained, skillfulness confidence. According to the informants, those who possess these criteria are competent can be appointed as a member of the Doktor Muda club. These findings differ slightly from the competence dimensions used in Hovland \& Weiss (1951); Berlo \& Lemert (1961); Bower \& Philips (1967); Whitehead (1968); Mc Croskey (1974) that stated that competence involves intelligence, expertise, and being informative. On the other hand, the two criteria obtained from the discussion are similar to the previous criteria, namely efficiency and well-trained.

The third dimension obtained is attractiveness. The informants in the focus group discussion stated that a student who wants to be a member of Doktor Muda should possess several criteria, such as good academic achievement, creativity, leadership, being caring or responsible, and have an attractive appearance. This finding is quite different from the criteria under the dimension of attractiveness used by Ohanian \& White (1990). These studies explained that attraction involves the criteria of being likable, familiar, and similar. The differences between the researchers' views may be due to the target group and the purpose 
of the study. In this study, the researchers measured the credibility of Doktor Muda members who acted as conveyors health information in primary schools while Ohanian and White measured credibility in product marketing and advertising. Indirectly, this difference gives a new perspective on the development of source credibility theory.

The last dimension discussed by the informant is dynamics. The informant clearly stated that a dynamic person is a person who is aggressive, courageous, energetic, responsive, friendly, dedicated, and wise. To become a member of the Doktor Muda club, one must possess these criteria. According to the informant, Doktor Muda should not be appointed among students who do not have the courage, weak, and not committed. These findings indirectly support the dynamics dimensions used by Berlo \& Lemert (1961); Whitehead (1968); White (1990) which stated that the dynamics dimensions include criteria such as aggressiveness, firm, being energetic, responsiveness, and friendliness. As a conveyor of health information, members of the Doktor Muda club must possess the criteria stated by the study informant.

\section{Conclusion}

In general, the four dimensions of source credibility obtained from this focus group discussion have shown the differences between source credibility dimensions obtained here and the source credibility dimensions found in previous studies. Previous studies have highlighted the dimensions of competence, dimensions, expertise, and trustworthiness, as used by Hovland \& Weiss, (1951); the dimensions of expertise and trustworthiness by Hovland, Janis \& Kelley, (1953); competence, trust, and dynamics by Berlo \& Lemert (1961); competence, objectivity, dynamics, and trustworthiness by Whitehead (1968); dimensions of security, qualifications, and dynamics Berlo, Lemert \& Mertz (1969); dimensions of attractiveness, expertise and reliability (Ohanian, 1990), dimensions of competence, trustworthiness and responsibility (Mc Croskey, 1999) and dimensions of expertise, trustworthiness, and attractiveness (Perloff, 2003). The difference in the application of these dimensions proves the development of the resource credibility theory, which also spans the fields of politics, education, advertising, marketing, and health. The applications of trustworthiness competence, attractiveness, and dynamics dimensions in this study also indirectly prove that source credibility dimensions can be used in school health promotion programs involving 12-year-olds to measure the credibility of Doktor Muda members as health information communicators to their peers at schools, especially in promoting healthy lifestyle practices.

\section{References}

Ali, S. (2015). Keyakinan kendiri Doktor muda dalam kemahiran mendemonstrasi membasuh tangan di Kuala Terengganu. Tesis Sarjana Sains Kesihatan (Pendidikan Kesihatan), Fakulti Sains Kesihatan, UKM.

Berlo, D. K., \& Lemert, J. B. (1961, December). An empirical test of a general construct of credibility. In annual convention of the Speech Association of America, New York.

Eisend, M. (2006). Source credibility dimension in marketing communication-a generalized solution. Journal of Empirical Generalisation in Marketing, 1-33.

Golan G. J. (2010). New perspectives on media credibility research. American behavioural science, 54(1), 3-7.

Hovland, C. I., \& Weiss, W. (1951). The influence of source credibility on communication effectiveness. Public Opinion Quarterly, Winter: 635-650. 
Hovland, C. I., Janis, I. L., \& Kelley, H. H. (1953). Communication and persuasion; psychological studies of opinion challenge, New Haven. Yale University Press.

Ibrahim, S. D., Sutan, R., \& Abd Manaf, M. R. (2019). Perlaksanaan Program Doktor Muda Di

Malaysia Dan Halangannya. e-Bangi, 16(5).

Institut Penyelidikan Tingkalaku Kesihatan. ( 2017). Laporan Kajian: Keberkesanan pendidikan rakan sebaya oleh ahli kelab Doktor Muda terhdap pengetahuan, sikap dan amalan kesihatan rakan sebaya. Kuala Lumpur.

McCroskey, J., Linda, L. M., \& Richmond, V. P. (2006). Analysis and improvement of the measurement of interpersonal attraction and homophily. Journal Communication Quarterly, 54(1); 1-31

Jaafar, N. (2010). Laporan kajian The force multiplier principle in improving equity and access to health education for school children: some lessons from the Doktor Muda Program, Universiti Malaya. Kuala Lumpur.

Ohanian, R. (1990). Construction and validation of a scale to measure celebrity endorsers perceived expertise, trustworthiness and attractiveness, Journal of Advertising, 19 (3), 39-52.

O'Keefe, D. J. (1990). Current communication: An advanced text series 2. Persuasion Theory and research. Thousands Oaks, United State: Sage Publications.

Perloff, R. M. (2003). The dynamic of persuasion:Communication and attitudes in the $21^{\text {st }}$ century, $2^{\text {nd }}$ edition. Mahwah NJ US, Lawrence Erlbaum Associates Publishers.

Pornpitakpan, C. (2004). The effect of celebrity endorser's perceived credibility on product purchase intention. Journal of international consumer marketing, 16 (2):55-74

Pertubuhan Kesihatan Sedunia. (2003). Health promoting school Report 2003 (South East Asia), Australia.

Seile, R., \& Kucza, G. (2017). Source credibility model, source attractiveness model and match-up-hypothesis - an integrated model. Journal of International Scientific Publications, 11. 1-15.

Wathen, C., \& Burkell, J. (2002). Believe it or not: Factors influencing credibility on web. Journal of the American society for information science and technology, 53(2): 34-144

Whitehead, J. L. Jr. (1968). Factors of source credibility. The Quarterly Journal of speech 54. 9-63.

Metzger, M. J., \& Flanangin, A. J. (2008). Digital media and youth: Unparalled opportunity and unprecedented responsibility, The MIT Press, 5-28, Camridge. 